\title{
Analysis of the Causes of the Independent Movement of Algeria
}

\author{
Rabeya Khatun \\ Islamic History and Culture Department, University of Dhaka, Bangladesh.
}

\begin{abstract}
The aim of this paper is to identify and analysis the different causes of the Algerian War of Independence 1954-1962. The analysis extends to include various aspects of French colonization's policy and their determination to maintain direct control of Algeria because of its strategic location and how they pillaged the land, destroyed old cultures, displaced local languages, transformed ancient customs, devastation of traditional society, economy and military alliances and how they created new ones throwing up in their wake new historical opportunities. It represents the undermining of women's roles and rights, and the exploitation of their willingness to shelve their feminist agenda in favor of participation in the nationalist cause. This paper also looks at the role of nationalist parties and leaders to rise of Algerian nationalism. This paper is traced to the nature of the socio-political Circumstances of Algeria that took over the leadership of the anti-colonial struggle, war of independence and subsequently of the Algerian state.
\end{abstract}

Keywords: Algeria, colony, nationalism, women, independence.

\section{Preface}

It was the century of colonialism. The principal colonial powers were the United Kingdom, France, Russia and the Netherlands. The nations of Europe fanned out across the globe in search of profits and in the process subjugated vast regions of the earth, pillaging the land, destroying old cultures, displacing local languages, transforming ancient customs. They played with the nations of Asia and Africa as if they were playing with pieces on a chess board that could to be captured and removed off the board at will. By the second half the $19^{\text {th }}$ century there was a broad understanding between these powers about colonies and regions of influence. The $20^{\text {th }}$ century witnessed a rising tide of resentment against colonial rule. As all other colonies Algeria was exploited by the French and his people were treated a little better than cattle. The French occupation of Algeria showed the classic signs of colonialism, and was characterized by rabid racism, religious bigotry and exploitative capitalism. The peoples of Algeria were pawns, second class citizens at best and slaves at worst, their resources at the disposal of the colonizing power, their destinies decided in European capitals tens of thousands of miles away from home. Political movements arose calling for the rights of them. It was a slow, tortuous and painful struggle. The French colonial powers were dug in by a Nationalist movement in Algeria. The Algerian war for independence is known as one of the most brutal and violent confrontations in the world's recent history. Independence movements, such as "Etoile nordafricaine" had been present in Algeria since the late 1920s. ${ }^{1}$ The war was characterized by torture and brutality against the Algerian Muslims and terror on the part of the resistance. The war became emblematic for the struggle of the colonized, cowed but not crushed against the colonizer. ${ }^{2}$ The start of the global decolonization movement followed the end of World War I. The first calls for Algerian autonomy came from upper class Algerians who could afford a French education and who took inspiration from the Arab nationalism of the 1920s and 1930s. Following the conclusion of World War II, tensions resulted in violence. The political leaders of the Algerians had been committed to reforming the French Republic by winning equal rights for Algerians within it. Algerian nationalist leader also played an important role for freedom. People like ${ }^{3}$ Emir Abd al Qader, Ahmed Ben Bella, Messali Hadj, Hadj Ahmed Bey, Abane Ramdane, Krim Belkacem, Larbi Ben M'hidi, Mostefa Benboulaid, Colonel Amirouche, Ferhat Abbas, Yacef Saadi, Ali Ammar, Hassiba Benbouali and female hero of the revolution are Djamila Bouhired and Lalla Fatma N'Soumer among others provided leadership and mobilization which encouraged the emergence of nationalist all over the country. On May 8th, 1945, VE Day marking the end of the 2nd world war, police massacred Algerians who supported independence movement in Setif. The police opened fire on a group of nationalists who parading with the illegal flag of the independence movement. This led to a small-scale revolt, which ended in the deaths of a hundred settlers ${ }^{4}$ which massacre provided the catalyst for violent outbursts to become a more regular occurrence. The National Liberation Front (FLN) began the liberation movement on November 1st $1954 .{ }^{5}$ The conflict ended on July 1, 1962, with Algeria obtaining independence at the cost of as many as 300,000 Algerian dead. The amount of Algerian casualties in the conflict is not possible to accurately establish. As an indication of the extent, the Algerian Ministry of War Veterans claims that over 150,000 members of the FLN were killed in the fighting." ${ }^{10}$ The FLN estimated in 1962 that nearly eight years of revolution had cost 300,000 dead from war-related causes. Algerian sources later put the figure at approximately 
1.5 million dead, while French officials estimated it at 350,000. ${ }^{7}$ The Library of Congress Country Study of Algeria states: "French military authorities listed their losses at nearly 18,000 dead (6,000 from noncombatrelated causes) and 65,000 wounded. European civilian casualties exceeded 10,000 (including 3,000 dead) in 42,000 recorded terrorist incidents. According to French figures, security forces killed 141,000 rebel combatants, and more than 12,000 Algerians died in internal FLN purges during the war. An additional 5,000 died in the "café wars" in France between the FLN and rival Algerian groups. French sources also estimated that 70,000 Muslim civilians were killed, or abducted and presumed killed, by the FLN. ${ }^{8}$ This made the eventual decolonization and extrication, when over 1 million people departed the country after a ferocious war of independence between 1954 and 1962, perhaps the most difficult and painful example of its kind. At the height of the war, French army numbers in Algeria finally reached some 400,000 sufficient at last to quell the resistance, but not to stop the tide of history at the conference table: finally, in a referendum in 1962, the country voted overwhelmingly for independence. The Algerian war for independence began in 1954 and ended in 1962 when French President Charles De Gaulle pronounced Algeria an independent country on July 3.

\section{French Conquest Of Algeria}

Since the capture of Algiers by the Ottmans Oruch and Barbarossa in 1516, Algeria had been a base for conflict and piracy in the Mediterranean. France's most extensive trading with Africa had been its importations of food from the coastal region of Algeria, a wheat-producing area with a population of only around 50,000. During the Directory regime of the First French Republic(1795-1799), the Bacri and the Busnach, Jewish negotiants of Algiers, provided important quantities of grain for Napoleon's soldiers who participated in the Italian campaign of 1796. The French had bought wheat from Algeria during the French Revolution, and in the 1820s, Bonaparte refused to pay the bill back, claiming it was excessive. However, in 1820, Louis XVIII paid back half of the Directory's debts. The dey, who had loaned to the Bacri 250,000 francs, requested from France the rest of the money. ${ }^{9}$ In 1827, a French envoy in Algiers told the governor of Algeria that France still had no intention of honoring its debt to Algeria, and, it is said, the governor struck the envoy with a fly swatter and threatened to end permission for France to continue trading in Algeria. The colonial relationship between French and Algeria began when Charles $\mathrm{X}$ authorized the invasion of Algeria on the pretext of revenging the humiliation of the French consul in Algiers, who the Dey of Algiers had slapped in the face with a fly swatter for refusing to pay a debt owed by the French government. On the otherhand, France had reason for concern that Britain, which was pledged to maintain the territorial integrity of the Ottoman Empire, would move to fill the vacuum left by a French pullout. The French devised elaborate plans for settling the hinterland left by Ottoman provincial authorities in 1830, but their efforts at state building were unsuccessful on account of lengthy armed resistance.$^{10}$ Truthfully, he(Charles X ) authorized the invasion to distract his subjects from discontent at home. ${ }^{11}$ France's monarch, Charles X, in June 1830, sent an invasion force of 36,000 troops to Algeria, claiming that he was responding to the insult to his ambassador. On June 14, 1830, more than 600 French ships landed 37,000 men on the shores of Sidi Ferruch adjoining the town of Algiers. To face the French, the dey sent 7,000 janissaries, 19,000 troops from the beys of Constantine and Oran, and about 17,000 Kabyles. The French established a strong beachhead and pushed toward Algiers. It was captured after a three-week campaign, and on July 5 the Dey was forced to surrender and a treaty was signed guaranteeing the respect of property and religion, Hussein Dey fled into exile. By February 1831, 4,500 civilian settlers had moved in and were working the land. ${ }^{12}$ Invasion casualties and hesitations saw French military manpower fall to around 17,000 in the difficult year of 1831, but three years later fierce and unorthodox opposition had forced France to increase army numbers to almost double. ${ }^{13}$ On December 18, 1832, the French army attacked the Mosque of Djemaa Kechawah in the Casbah and transformed it into a cathedral. The most successful local opposition immediately after the fall of Algiers was led by Ahmad ibn Muhammad, bey of Constantine who initiated a radical overhaul of the Ottoman administration in his beylik by replacing Turkish officials with local leaders, making Arabic the official language, and attempting to reform finances according to the precepts of Islam. ${ }_{14}$ After the French failed in several attempts to gain some of the bey's territories through negotiation, an ill-fated invasion force led by Bertrand Clauzel had to retreat from Constantine in 1836 in humiliation and defeat. Nonetheless, the French captured Constantine the following year. Algeria became officially annexed to France on July 22, 1834. There were pitched battles in 1849, 1851,1852,1853,1857, 1864, 1870, and 1871 and again in 1881. And this in spite of agreements and treaties signed by both sides.

\section{Causes Of The Independent Movement Of Algeria:}

The France fanned out across the globe in search of profits and in the process subjugated vast regions of the Algeria, pillaging the land, destroying old cultures, displacing local languages, transforming ancient customs. They played with the people of Algeria as if they were playing with pieces on a chess board that could to be captured and removed off the board at will. The people of the colonized territories were pawns, second 
class citizens at best and slaves at worst, their resources at the disposal of the colonizing power, their destinies decided in European capitals tens of thousands of miles away from home.

1. In the course of French colonization of Algeria, discontent on the part of the inhabitants led to several uprisings. French colonization and settlement of Algeria, which began in the 1830s, destroyed the traditional infrastructure of Algeria. During the period, French immigrants to Algeria, or "pieds noirs", took over Algerian land, turning the country into a settler colony. The effect of the "pieds noirs" arrival on Algerian society was dramatic. By 1848, northern Algeria was fully under French control and became a "department" of France with civilian government. Many locals lost their land, and their traditional Muslim leaders were replaced by French officials. This angered many Muslims and eventually led to the rise of political elite that would challenge French control of Algeria. One such group became known as the National Liberation Front (FLN). To make room for the European influx, native tribes were broken up and forced on to unproductive lands. ${ }^{15}$ As the French began to control the tribes through a policy of indirect rule, 'indigenous affairs' officers were primarily interested in being able to communicate clearly with Berber and Arab leaders. Officers learnt indigenous languages, and gave a few 'Muslims' some basic training to enable them to understand what was expected of them and to be facilitates obedience from the locals. The French conquest of Algeria gave rise to a wave of government supported immigration to Algeria from these nations, in contrast to that which had been happening informally since the Middle Ages. Within the first few years they outnumbered the newly settled French population. ${ }^{16}$ One of the many ways in which France constructed Algeria as a fundamentally Roman, not Arab, place and asserted that France, as the inheritor of the Latin tradition should rule in Algeria, was by calling Algerian cities by their Latin names: for example Annaba became Bône again. ${ }^{17}$ By 1866, one in three European residents of Bône had been born there. The majority of these Europeans were Maltese and Italian, a trend that would continue until the twentieth century. ${ }^{18}$ The non-French, foreign-born population in Algeria grew more slowly after 1853 due to Napoleon III's view that the "Royaume Arabe" should have a limited population of colonists. ${ }^{19}$ As a result, in a letter to the Governor-General of Algeria from February of 1863, the Emperor demanded he enforce a sharp cut in foreign immigration to the Algerian countryside, a reversal of previous immigration policy that encouraged expanding French control of the cities' hinterlands. ${ }^{20}$

2. The major reason for the prolongation of the war was France's determination to maintain direct control of Algeria because of its strategic location. Seeking to integrate Algeria into the Third French Republic, France had made Algeria a part of France proper, whereas under similar circumstances it had given Morocco and Tunisia the status of protectorates. A royal ordinance in 1845 called for three types of administration in Algeria. The important impacts of colonization are:-

2.1 Colonization destroys the old social, economic and military alliances and creates new ones throwing up in their wake new historical opportunities.

2.2 The occupation of the northern coast attracted settlers from southern France looking for new economic opportunities. Colonization created a new class of French bureaucrats beholden to the settlers. The old Ottoman aristocracy in which local landlords and businessmen held high positions was destroyed and became subservient to the French bureaucracy.

2.3 In time the collusion of the settlers, called the colons, and the French administrative machine created a powerful lobby which no government in Paris could disregard. Although Algeria was annexed, it was legally not a part of France, but was administered as three "departments". The colons had representations in the French parliament but not the Muslim Algerians. The one sided political relationship between the occupier and the occupied created a corresponding imbalance in the economic and social conditions on the ground.

2.4 Agricultural land owned by Algerians was confiscated, often arbitrarily, and given to the settlers who amassed huge plantations and grew rich in the process.

2.5 The displaced Algerians were forced to become laborers and servants for survival. As economic disparities grew, so did the social chasm between the settler and the native.

2.6 A sociology of discrimination emerged which justified the economic and political stratification as a natural order.

2.7 By 1848 nearly all of northern Algeria was under French control. Algeria was so conveniently close that the Algeria would be "just another part of France", it followed that Algerians would be subject to French rules and taxation .So in 1865 Napoleon III gave Algerian Muslim legal equality with the "pieds noirs", but denied them full citizenship. They "could enter the French civil service, enlist in the army, and migrate to metropolitan France." But they could not attain French citizenship.

The colonial wars had the indirect consequence of French penetration into the interior of the country. The policy of land confiscation and its distribution to the colons was now extended to the Atlas highlands. The local farmers were increasingly squeezed into less productive lands. Traditional centers of power based on land ownership were destroyed. The Algerian farmer had no choice but to become a sharecropper on land owned by the colons or to migrate to the larger cities along the coast and seek employment in menial jobs working for the immigrant Europeans. 
3. The movement for independence came from the Algerians' dissatisfaction with being treated as second-class citizens by the French colonial government. The French government was aware of the growing social and political imbalances but was divided on the issue of Algeria. The French emperor Napoleon III did make a feeble attempt to stop the arbitrary seizure of Algerian lands in 1863 but had to rescind the measures in the face of hostility from the entrenched colons. In the colonial order, the Algerian Muslim had two strikes against him, one because he was an Algerian, and the other because he was a Muslim By 1870, under the rule of Napoleon III, locals were allowed to apply for French citizenship, and this was granted most frequently to Jews but not to Muslims. The Sephardic Jews were accorded full citizenship in 1870 as if to proclaim openly that religion was a key criterion in the discriminatory and oppressive emerging colonial order. Christians and Jews could become full citizens; not so the Muslims. The statutes offered French citizenship to a handful of Muslims provided they gave up their allegiance to the Shariah. This was tantamount to giving up their religion and few Muslims took up the offer. Napoleon III decision to give Algerians legal equality but not French citizenship formed the roots of the Algerian identity crisis: the French would always treat Algerians as quasi citizens with quasi-French qualities; that is, the Algerians were almost but not quite French Islam, was of course, the main reason to deny Algerian full citizenship .The only way for an Algerian to gain full citizenship was to renounce Islam."Only several thousand were willing to do so. ${ }^{21}$ The Algerian dilemma, which continues even today, is laid out in this policy. While Algerians want to have all the rights of every other French citizen, their refusal to renounce Islam has kept them from attaining full citizenship. The discriminatory laws had a definite religious angle to them. Napoleon III's foreign policy regarding Algeria was profoundly influenced by Ismail Urbain, a translator and writer who served in the French Army during the Algerian conquest and whose political advice the French government in Algeria and the Emperor held in high regard. Urbain was born out of wedlock in Guyana, to a French father and an African mother. He later converted to Islam and taught French in Egypt, before learning Arabic and going to Algeria to participate in the conquest.

4. Europeans were more interested to spread their ideology of capitalism in Algeria. The settlement of large numbers of European settlers in different parts of Algeria caused growth of Algerian's nationalism. Concurrent with the French military occupation of Algeria, migrants seeking adventure and economic opportunities arrived in Algeria from a variety of European countries foremost among them Italy, Malta, and Spain. ${ }^{22}$ The Spanish connection with the Maghreb has deep historical roots, for Arabs ruled in Spain during the Middle Ages and later Spanish governments influenced politics in North Africa. ${ }^{23}$ Maltese and Italian immigrants begin arriving in eastern Algeria in 1834, predominantly settling in Bône and Philippeville, a city east of Bône on the Gulf of Stora. All three nations had long-standing familiarity with Algeria in its decades as an Ottoman province. During the seventeenth and eighteenth centuries, Maltese privateers collaborated and competed with Barbary pirates in the Mediterranean. A steep increase in population during the early nineteenth century overwhelmed the island's capacity and many Maltese immigrated to Algeria to exploit this opportunity to work as smugglers and contraband dealers, as well as more legal pursuits. ${ }^{24} \mathrm{~A}$ demographic shifts occurred in western Algeria, particularly in Oran and Algiers, where Spanish immigrants constituted the majority European population ${ }^{25}$ The first wave of immigration occurred between 1830 and 1848 and consisted mostly of immigrants from Majorca, Minorca, Valencia, and Alicante who engaged in prostitution, smuggling, and goods trafficking with the French army and the indigenous population. ${ }^{26}$ By 1851 there were 20,872 people of Spanish origin living in the department or Oran and 20,686 in the department of Algiers. ${ }^{27}$ The number of Spanish residents of Oran to be granted citizenship per year between 1865 and 1889 topped one hundred only once, in 1887, even though the local population had reached 58,000 by $1886 .^{28}$ The European wanted to be free to pursue their trading interest in Algeria's wanted to spread the ideology of capitalism. The increasing European population in Algeria played a big role in the growth of Algerian nationalism. This caused destruction of Algerian culture, property, hunger and other forms of sufferings also exposed Algerians to segregation. This caused the need to fight for political freedom and self determination.

5. The French occupation of Algeria was not originally intended to further settler colonialism. The government undertook the invasion for political reasons relating to Charles X's waning popularity, a desire for agriculturally exploitable territory, and the notion that France had a responsibility to civilize non-Europeans. ${ }^{29}$ But, in the 1850s and 1840s, private citizens of varying nationalities and soldiers went to Algeria take advantage of the French version of the American frontier. It was lawless, violent, and full of shady business opportunities. As a result, between 1850 and 1870, the settler population in Algeria did increase but the majority of immigrants were not French, native or naturalized, but peasants looking to escape military duty, drifters, and criminals from Southern European nations. ${ }^{30}$ Dealing with this influx of foreign immigrants Problematized the "Frankness" of Algeria and forced the republican government in Paris to readdress how the state should legally re-categorize. The disparity between the Spanish and the French population increased dramatically from 1861-86 and by 1886 the Spanish population had climbed to upwards of 90,000 while the French population hovered around 64,000. In the 1876 edition of the État actuel de l'Algérie, published by the general civil government of Algeria under the direction of M. le Meyre de Vilers, the director general of civil and financial affairs in Algeria, the senator 
General Chanzy wrote, "after 1871, populating Algeria with French or naturalized immigrants was the principle objective of the central administration." Expanding the French empire abroad would bring more resources to the nation at home, provide more outlets for the republican civilizing mission, and give France more leverage in power relations on the continent. ${ }^{31}$ During the 1870 s and 1880 s, promoting a more expansive imperial agenda more generally and settler colonialism in Algeria specifically became one of the main foreign policies of the Third Republic. This drive for territorial expansion was propelled in part by the same falling birthrates that prompted increased immigration to the metro pole. ${ }^{32}$ By 1889 , the vast majority of European immigrants to Algeria were still foreign nationals, even though citizenship In a letter from 30 September 1884, the GovernorGeneral reiterated his position that the situation in Algeria "was much more serious than ever before" and needed immediate "energetic measures" if it was to be rectified before the foreign population completely outnumbered and could overpower the French. In the context of the burgeoning debate on immigration to France, the presence of foreign nationals as Algerian colonists influenced and encouraged domestic discussions on immigration the French seemed that occupation of Algeria was not originally intended to further settler colonialism. The government undertook the invasion for political reasons relating to Charles X's waning popularity, a desire for agriculturally exploitable territory, and the notion that France had a responsibility to civilize non-Europeans. The concept of the civilizing mission has a history of its own. In short, it arose out of post-enlightenment assumptions that French culture and political universalism made France superior to other nations. Because France was better off, the nation had a responsibility to 'civilize' 'oppressed peoples. ${ }^{, 33}$ It was an inauspicious beginning to France's self-described "civilizing mission " whose character on the whole was cynical, arrogant, and cruel. In the 1844 version of his book on the history of Algeria Léon Galibert, a historian who was generally in favor of "this intelligent and liberal intervention," reflects on the background to France's "civilizing mission" in Algeria:

"France took its turn, after so many other famous peoples, to impose its laws on North Africa; to her fell the difficult and dangerous mission of reviving and expanding in this land the civilization which Rome in former times had their deposited. ... Islamism, in its deplorable state of decline, was unable to regenerate anything. So a new, strong people was needed, governed by generous notions and the great principle of humanitarianism, to bring Africa out of the mindless state into which it had been plunged by twenty centuries of oppression, war, struggles and invasion....It must be said in passing, however, that initially the expedition which gave France possession of Algeria was not exactly conceived along these broad social lines, and even less with a view to a permanent establishment. All that France sought was to obtain redress for particular grievances, and only secondarily to smash piracy, abolish the enslavement of Christians, and put an end to the shameful tribute which the maritime powers of Europe were paying to the Regency." ${ }^{34}$

But in the 1850s and 1840s, private citizens of varying nationalities and soldiers went to Algeria take advantage of the French version of the American frontier. It was lawless, violent, and full of shady business opportunities. As a result, between 1850 and 1870, the settler population in Algeria did increase but the majority of immigrants were not French, native or naturalized, but peasants looking to escape military duty, drifters, and criminals from Southern European nations. ${ }^{35}$ Dealing with this influx of foreign immigrants problematized the "Frankness" of Algeria and forced the republican government in Paris to readdress how the state should legally re-categorize settled immigrants. By 1871, any Algerian rebels who resisted colonization were defeated, and Algeria became a "small French Republic" in which only the interests of the French settlers counted. The voter's cards became the title of nobility in this novel feudal system ${ }^{.36}$

6. Algeria was also occupied in 1830 at a tremendous human cost. The population of Algiers was reduced from its eighteenth century peak of 75000 to just $300000^{37}$ The course of French colonization of Algeria In 1834 France annexed the occupied areas, which had an estimated Muslim population of about 3 million, as a colony. ${ }^{38}$ Due to outbreaks of malaria, cholera, and continuing violence between the native and colonist populations, the death rate for all immigrant populations was particularly high during the early migration waves, but the sheer number of settlers kept the European population growing at a faster rate than the native population. ${ }^{39}$ There were 3 million Algerians when France invaded in 1830 - 20 years after the population had fallen to 2 million, and by 1867-68, it had fallen by 600,000 due to famine. ${ }^{40}$ More than 200,000 Algerians perished in the famine. Decreasing Algerian peoples are one of the causes to raise the nationalism because of weakness and power.

7. Gambetta characterized the French government as having a serious responsibility. Though the proportion of French to foreign citizens in Algeria would only decrease during the first decades of republican rule, French politicians at the time encouraged French citizens to move to the colony, asserting that through the expansion of the nation's overseas holdings, France would rise to prominence again. Following the uprising of the Paris Commune in 1871, Prime Minister Jules Ferry, a great supporter of French colonial expansion remarked, Following the uprising of the Paris Commune in 1871, Prime Minister Jules Ferry, a great supporter of French colonial expansion remarked, "You say that you wanted a France great in all things, great in the arts of peace and colonial politics...For wealthy nations, colonies are the most advantageous repositories of capital. Is that not the interest that we have for capital in this country? I say that France, which is overflowing with capital and 
exports considerable quantities of goods, has interest in considering the colonial question. For Ferry, colonialism would lead to renewed economic success for France, providing new markets for French goods without the tariffs associated with trading among the United States and Germany. Ferry worried that France would lose its influential position in European politics if the government failed to create sustainable, forward- thinking colonial policy. ${ }^{40}$

8. The significance of this colonization lies not only in the fact that it lasted for more than 130 years but also, and more importantly, in the structural changes and transformations that it reacted in Algerian society. ${ }^{41}$ The devastation of traditional society of Algeria played a major rule as a cause to raise their voice against France government. Pre-colonial Algerian society, which was variously affected and conditioned by this colonization, was totally changed and its ways of life drastically altered. The effects of French colonization are more evident in the agricultural sector than in any other sector of the economy. A set of new socio-economic relationships was introduced, based on private property in land and on the production of exchange value and the gradual substitution of a market for a subsistence economy. The foundations of rural society were violently destroyed by privatizing and expropriating its essential means of production, i.e. the land, and transferring ownership to a relatively small number of European settlers, who developed their agriculture on a capitalist basis, and linked it directly to metropolitan France. They created large agricultural tracts, built factories and businesses, and exploited cheap local labor. The European settlers were largely of peasant farmer or working class origin from the poor southern areas of Italy, Spain, and France. Others were criminal and political deportees from France, transported under sentence in large numbers to Algeria. In the 1840s and 1850s, to encourage settlement in rural areas official policy was to offer grants of land for a fee and a promise that improvements would be made. According to historian John Ruedy, "although by 1848 only 15,000 of the 109,000 European settlers were in rural areas, "by systematically expropriating both destructing of traditional pastoralists and farmers, rural colonization was the most important single factor in the society." 42

9. An Algerian Muslim could enlist in the French army and was permitted to shed his blood for the empire but he could not become a French citizen unless he was willing to give up his allegiance to the Shariah. The Algerians were not just second class citizens; they were not citizens at all in their own land and were considered by the settler Europeans as no more than serfs worthy of benevolent patronizing at best and contempt at worst.

10. The worsening social condition of the Algerian Muslims was manifest in their educational backwardness. The revolution's philosophical foundations came from the privileged Algerians who were Gallicized by the French education system .The old madrasa system was destroyed by the French. Roads and schools were built but these were for the Europeans only Traditional education based on the Madrasa system was decimated while access to French education was restricted. Lycees or high school similar to those in French sprang up in North Africa, but these were reserved for the French and the colons. The Algerians were reluctant to send their children to the Lycees lest they inculcate alien values. But even if they wanted to, Algerian Muslim children were not welcome in French schools. The educational backwardness was most conspicuous in the predominantly Muslim hinterland which received little investment in the educational infrastructure and was at best treated with benign neglect. Illiteracy among the Muslim population was widespread, and nothing was being done to reverse this situation. Although there was no legal segregation, few Muslim children attended school, for instance. An early attempt at mixed French and Muslim primary and secondary schools had little success but after 1920 improvement was achieved. 1948 statistics show that $90 \%$ of boys age ten and up were illiterate compared to $96 \%$ of girls that age. These numbers reflect the lack of investment on behalf of the French government in education for all Algerians. Specifically, Algerian girls were victims of a patriarchal system that regulated the movement of girls in the public space. In 1949, French and Muslim primary schools were merged. In 1958, only 12 percent of all children attended school. ${ }^{43}$ Using of Arabic language was discouraged and its place taken up by French. Illiteracy increased so much that in 1960, after 120 years of French rule only ten percent of Algerian Muslims could be considered literate.

11. The Algerians who did not immigrate to France were still surrounded by the French language, which was used in politics and the press, and above all, [it was] the language of technology and modern economic management without any transitions into Arabic. As a result, in 1923, Arabic was even declared foreign to Algeria because it was seen as an Arabic language not useful for modernizing Algeria."44 For Algerians, the French language became the ultimate symbol of France's tyranny and of the permanent damage colonization would inflict upon their lives. Even after decolonization, the French Algerians, who had no choice but to speak it, since they knew no other Language. ${ }^{45}$ The French language was imposed on the natives because France did not view Algeria as just another colony. France sought to make Algeria an extension of France itself. Algeria, being just an Ocean's crossing away, was referred to as the "Second France". 46

12. It was a time of great economic dislocations in Europe. The Nazis had come to power in Germany, riding on a wave of mass unemployment and economic collapse. America was in the grip of the Great Depression. The French needed social peace on the home front. The proposals were abandoned because of the determined opposition of the colons. The economic decline in Algeria, which was worsened by the two world wars, gave the 
Algerians more incentive to start a nationalist movement. The movement towards Algerian liberation from France came at the end of a long period of economic decline that began with the displacement of Algerian tribes in the 1830s and was then shaped by the two world wars. The Algerians nationalist movement occurred roughly between the conclusion of the two wars beginning in 1919 after W.W.I and resulting in the start of the Algerian liberation war in $1954 .{ }^{47}$ The two world wars helped in general to weaken all Europeans' control of their colonies, but the French stubbomly remained convinced that Algeria was already too much a part of France to ever be lost. But the economic decline in Algeria, which was worsened by the two world wars, gave the Algerians more incentive to start a nationalist movement. Ruddy explains: The Algerian nationalist movement appeared and developed within the context of a progressively detenorating economic situation which was caused by the conjuncture of negative world market forces, a series of bad crop years at home, and demographic pressures, all of which contributed to the growing disequilibrium within the economy as a whole. ${ }^{48}$ By the end of 1st W.W in 1919, according to Ruddy, the war effort had caused major inflation; industrial prices were rising much more quickly than the prices of agricultural products, which were the base of the Algerian economy; surpluses of unsold grain were adding to the economy troubles; and in 1920, crops were failing as they had previously done in 1866-1870. To add to this, there was a postwar epidemic of a flu known as la grippe espagnole, which took a toll on the population. ${ }^{49}$ A typhus epidemic and additional shortage followed in 2 nd WW, ravaging the population once again in $1942 .{ }^{50}$ Dire unemployment had already hit the country in between the two wars because of the worldwide depression of the 1930s. But the 2nd world war made Algeria's lack of the "most elementary industrial base painfully clear" as the country experienced shortages of energy and machinery. ${ }^{51}$ Algerian immigration steadily increased during France's occupation of Algeria, spurred by several factors. The loss of land and displacement resulted in the unemployment and poverty of many Algerians, who were then forced to seek job opportunities in France. ${ }^{52}$ Initially, it was caused by the displacement of Algerians especially those from kabylia, who left to work on colonial farms, but many eventually moved to France. The shortages of $1 \mathrm{st}$ w. w caused France to recruit workers of Algeria. After 2nd world war, there were up to 350,000 Algerian men working in industrial jobs in Paris, Lyon and Marseille, and the independence war itself caused many Algerians to move to France to avoid the violence. ${ }^{53}$ Thus, since the world wars forced many Algerians to immigrate to France for economic reasons, the increasing exposure to western rights in France allowed Algerians to see the inequalities between themselves and French citizens. Martin Stone, in the Agony of Algeria, like Aaron, says that "The First World War can be taken as the true starting point of nationalist aspirations among the Muslim community in Algeria. It was around this time that Muslims who had been forced to immigrate to France became aware of democratic and egalitarian principles vigorously suppressed in Algeria, and of the emergent Arab nationalist movements in states of the Arab east. ${ }^{54}$ On the other hand, in 1909, for instance, Muslims, who made up almost 90 percent of the population but produced 20 percent of Algeria's income, paid 70 percent of direct taxes and 45 percent of the total taxes collected. 'The peasants do become industrial workers, but only in France'. ${ }^{55}$ Migrant labor was an escape valve for the social pressures building up in Algeria, but in the fifties, an economic downturn shut down the valve. The national struggle erupted and found its social basis in the underemployed landless laborers, men who were called by the FLN's most eloquent spokesman, Frantz Fanon, 'The Wretched of the Earth'. So more than the hardships faced by Algerians, it was the comparisons between their lives and that of French, which they were now able to make, that awakened the nationalist movement. The fact the France also depended on Algerian during both world wars revealed to the Algerians that their colonizers were vulnerable and certainly not invincible. During the $1^{\text {st }}$ world war, Algerians were conscripted into the French army, and though many Algerians willingly accepted service, at the same time, Aaron writes that they felt they deserved better treatment for their sacrifices. The Algerians had a list of what they wanted including: ${ }^{56}$ [Translation]

12.1. The suppression of the indigenous code and of fiscal inequalities.

12.2 The diffusion of teaching.

12.3 The increase in number of Muslim representatives in elected assemblies.

12.4 French citizenship compatible with the preservation of Muslim law.

These revindications seem outrageous to Europeans who see in them aspirations towards independence and who speak of Muslim nationalism. Wars in Europe and increasing commerce between Algeria and France had driven up the price of Algerian wheat to world market levels and the peasants had sold their reserves to speculative French hoarders. The administration reneged on its promise to advance loans to the farmers to replenish their seed grains exhausted by years of famine. Sheikh al Haddad declared a jihad against the French, mustered a force of 100,000 tribesmen and marched on Constantine. Lacking modern firearms and the discipline of modern armies, the uprising was quickly down and Sheikh al Haddad was captured. Following the insurrection, the colonial administration instituted harsh statutes against the Algerian Muslims which sanctioned arbitrary arrest and imprisonment, abrogation of the right to assembly and severe punishment for the slightest disrespect to French officials. 
13. The Algerian war of Independence 1954-1962 has become emblematic of the incompatibility of feminist and nationalist movements. This war represents the victory of the colonized through the sanctioned use of violence. It also represents the undermining of women's roles and rights, and the exploitation of their willingness to shelve their feminist agenda in favor of participation in the nationalist cause. Women experienced colonialism in ways much different than men in Algeria. Despite this attitude, however, French policies towards Algerian women's rights were ambiguous and never significantly improved under colonization. By 1954, when war broke out, women were completely excluded from public life. Only $4.5 \%$ were literate, few had jobs or went to school, and they had no voting rights. ${ }^{57}$ Until the revolution, Algerian girls attended schools at the rate of one in sixteen, while Algerian boys had attended at the rate of one in five. ${ }^{58}$ In 1948 statistics show that $90 \%$ of boys age ten and up were illiterate compared to $96 \%$ of girls that age. These numbers reflect the lack of investment on behalf of the French government in education for all Algerians. Specifically, Algerian girls were victims of a patriarchal system that regulated the movement of girls in the public space. ${ }^{59}$ Some argue that throughout Algeria's history, the status of women has been inferior to men and they have often times been misrepresented, politically, socially, and economically. ${ }^{60} \mathrm{We}$ begin with a short detour through the national movement. The goal is to determine the significance of the woman question in the eyes of the protagonists and actors of the national movement. Prior to the war of liberation (1954-1962), there were three associations of women, created between 1934 and 1947: the women's section of the Algerian People's Party (PPA), the Union of Algerian women, and the Association of Muslim Women of Algeria. The entrance of women into the political arena was therefore made under the umbrella of political parties. Women joining these structures were bound to adopt the programs of these political parties. These programs concentrated either on labor struggles, especially for women's associations affiliated with the Communist Algerian Party (PCA), or anti-colonial struggles, particularly for the women associated with the PPA. These associations may be considered as satellites of the political parties, used for transmitting their ideologies to the women's circles. Concerning the woman question itself, the political parties approached it by adopting one of the following two formulas:

- The woman question is not a priority.

- The woman acquires her rights through participating in the struggle for national liberation.

This approach was also that adopted by the various nationalist leaders and also in the founding text of the war for national liberation. ${ }^{61}$ The torture of women under arrest revealed "the state's view of women," Algerian women and female combatants were not the only female victims of torture in detention centers. ${ }^{62}$ The French Army also arrested European women sympathetic to or actively aiding the Algerian nationalist cause. Natalya Vince notes archival documents of seven European women imprisoned at the Villa Sésini detention center in Algiers. ${ }^{63}$ Vince comments on the futility of the women's appeal for release by writing letters to high-ranking military authorities. Just like these seven women, most political prisoners faced a legal vacuum in the military tribunal system. ${ }^{64}$ Although Algeria was colonized in 1830 for mostly economic and political reasons, it was justified under the guise of "la mission civilisatrice" (civilizing mission) in part because the French saw Algerian culture as backwards and underdeveloped, especially in regards to their treatment of and behavior towards women. To the French, Algerian women were seen as the "oppressed of the oppressed." 65 The French government and army became concerned with reports of female involvement in the leading independence group, the National Liberation Front (FLN), and decided to offer a "counter-strategy to win hearts and minds." 66 The French believed that appealing to women by improving their status would break up the independence movement, since women were seen as symbols of Algerian national identity and culture. ${ }^{61}$ Previously, under the "statute personnel" (personal status law) of the colonial regime, the French had asserted their dominance by denying Algerians equal rights as French citizens; that would target women's rights within marriage, family law, and education. These policies were intended to liberate Muslim women from the "ignorance and the crushing weight of patriarchal domination." 67 Their main plan for retaining "l’Algérie française" (French Algeria) was stopping the rebellion through economic modernization and social reforms that promoted women's education, voting rights, unveiling campaigns, health care, and jobs. ${ }^{68}$ However, the colonial government promised to protect Islamic law in the crucial area of marriage and family legislation, a 'reserved' area that would be guarded from the incursion of western values and secular French models of society." ${ }^{69}$ Despite this agreement, in the midst of armed conflict in 1959, the French regime attempted an alternate approach at gaining support from Algerians by enacting a series of "reformist, liberal emancipation measures" In reality, the so-called emancipation reforms actually put the majority of Algerian women at a disadvantage. The changes to marriage law were ignored, especially in rural areas, and the reforms generated intense backlash towards women's rights. Many Algerian men felt threatened by the "moral interference" of the French reforms and promotion of women's rights, fearing that women would become powerful and threaten social order and tradition. ${ }^{70}$ They considered the reforms an attack on Islam and Algerian culture, which they resisted by emphasizing the necessity of religious values, family, and the modest dress and seclusion of women. ${ }^{71}$ Many women were also subjected to rape: since virginity is highly regarded in Algeria culture as a facet of While the FLN recruited a small number of women as fighters, they encouraged women to support their struggle through what they called 
"patriotic motherhood": being good wives and mothers who would teach their sons to value religion and "preserve traditional moral standards" as a way of molding. In particular, the traditional image of women in Algerian society came to symbolize the national identity the FLN was fighting for. ${ }^{72}$ Women's participation in the liberation struggle, however, seemed poised to challenge this notion of the traditional Algerian woman. Writing about the revolution, anti-colonialist author and psychologist Frantz Fanon predicted the "birth of a new society" and a "radical mutation" of the status of women, gender relations, and traditional family structures. ${ }^{73}$ The FLN, however, had no problem using female fighters as propaganda for their cause. In response to the French emancipation reforms, the FLN launched its own publicity campaign, claiming "women could only achieve equality by fighting for a country freed from colonial domination." ${ }^{74}$ These women received attention in the global media as heroines of the revolution who were challenging stereotypes of Muslim women as passive victims of Islamic male oppression. The FLN's wartime newspaper El Moudjahid published weekly excerpts from a diary of a young female fighter. ${ }^{75}$ They also publicized stories depicting the sacrifices of Algerian female fighters in order to incite international protest against the French regime. "They discourse on Algerian women was an important weapon in combating the French government's depiction of a nationalist struggle as a minority movement led by religious fanatics with a pan-Arab agenda." ${ }^{76}$ The narrative of the Algerian female fighter supported a romanticized version of the anti-colonialism struggle, helping to bring the FLN sympathy and support. ${ }^{77}$ Although most of the attention on Algerian women during the war focuses on the most visible urban fighters, they were the minority: only a small percentage of women carried out terrorist attacks or were armed fighters. ${ }^{78}$ Despite this disparity, the French military and police did not spare women revolutionaries: about 2,200 women were arrested and tortured during the war. ${ }^{79}$ Many women were also subjected to rape: since virginity is highly regarded in Algeria culture as a facet of their Islamic religion, rape was a "particularly potent method of torture and abuse for women suspected of being nationalists. ${ }^{\prime 80}$ In 1974, Algeria's Ministry for Veteran's Affairs estimated that about 11,000 women fought in the war (making up about $3 \%$ of all participants) ${ }^{81}$ The violent decolonization of Algeria altered the political, social, and cultural landscape of both France and Algeria in ways that still resonate today. The conflict forced a re-consideration of "the universality of French culture" ${ }^{\prime 82}$ and by the war's end violence and social unrest had spread from Algeria to metropolitan France. It is important to stress that the fidayate comprised the minority of female resistance fighters during the French-Algerian War, only about 0.2 percent of the total population of women active in the Algerian resistance effort. ${ }^{83}$ Far from being passive observers, Algerian women participated in the nationalist resistance movement in a variety of capacities, from providing logistical and medical support to taking part in armed conflict. Most women working with guerilla units were young, with half under 20 and ninety-percent under 30 years old. ${ }^{84}$ Moudjahid also acted as political and social organizers, as women could access traditionally female spaces to inform rural residents about the role and political aims of the FLN. ${ }^{85}$ This distinct minority of Algerian-French Muslim women proved much harder for army officials to conceptualize and, therefore, rationalize or compartmentalize according to colonial stereotypes. Historian Natalya Vince has explored the French Army's misconceptions of this minority of Algerian women in depth, citing the memoirs of General Jean-Yves Godard. In his memoirs, Yves seemed "almost obsessed with the apparently Europeanized female bombers," Vince notes. ${ }^{86}$ By 1957 the French Army's use of torture was systematized, authorized, and reutilized. Any individual, whether a man or a woman arrested and deemed a rebel terrorist was subject to torture in detention centers. Torture in Algeria became a tactic of "normalized terror to forestall the collapse of the empire in an age of decolonization." ${ }^{87}$ French colonial officials, however, claimed that torture was an "epiphenomenon" 88 of the war; a reaction against the barbarity of rebel forces and attacks against European civilians, the result of a spontaneous convergence of circumstances that necessitated torture in order to maintain the security of the European population in Algeria and to prevent anarchy. Both men and women were subject to similar methods of sexualized torture in detention centers. Electrodes 55 were applied to the breasts and genitals. ${ }^{89}$ Men's testicles were crushed or burned away with electric shocks. ${ }^{90}$ Women and men could be raped with various objects. However, the consequences and implications of rape for women in colonial Algeria functioned differently than for men. ${ }^{91}$ Algerian Muslim women felt rape more keenly as a result of their place in their society and communities. Another soldier, Jean-Paul Meurisse, describes arriving back at his base camp to find his superior officer waiting with a dozen local women for the officers to choose from. ${ }^{92}$ The Furthering the notion that the torture of women under arrest revealed "the state's view of women," Algerian women and female combatants were not the only female victims of torture in detention centers. ${ }^{93}$ The French Army also arrested European women sympathetic to or actively aiding the Algerian nationalist cause. ${ }^{94}$ Natalya Vince notes archival documents of seven European women imprisoned at the Villa Sésini detention center in Algiers. ${ }^{95}$ Vince comments on the futility of the women's appeal for release by writing letters to high-ranking military authorities. However, as Marnia Lazreg writes, "more than men, women's bodies were subjected to greater indignity inside as well as outside the torture chamber." ${ }^{96}$ The French emancipator measures and official emancipation rhetoric "obscured the reality of women's rape on the ground." ${ }^{97}$ This in essence reveals the paradox of the mission civilization and the French Army's policies on women during the French-Algerian War. 
Women in France participated in elections for the first time in October of $1945 .{ }^{98}$ The French women's movement to create a 'new Algerian woman' who exhibited the rights of a true, free, liberal, empowered woman. This creation of a new Algerian woman' required education, Western socialization, and of course unveiling. Algerian women were highly illiterate and only represented an extremely small portion of the educated elite. These were the qualities that defined agency and power in France and therefore it only made sense to the French women that these values must be instilled in the minds of Algerian women as well. In the late 1920s and early 1930s, French women rallied the Algerian women in hopes to grant women suffrage rights in the colonies. French feminists viewed the colonies as grounds to speak out towards the rights of women. In 1947 the right to vote was extended to Algerian women as a reflection of their roles as citizens (albeit second class citizens) of the French Republic and in 1958 Muslim women participated in the elections for the first time. ${ }^{99}$ Until the Algerian women were assimilated to Western French culture, it was argued that France had defaulted on its promise of its 'civilizing mission'. ${ }^{100}$ Algerian women were also reluctant to position themselves alongside the French feminists. In the 1940s, the Algerian women's movement began to take root and became an important instrument for expressing female agency during the independence movement. Another example of the French control over Algerian female representation was in the form of literature. French women used Algerian authors to support their role as 'emancipators of Algerian women.' Rhaïs is an example of one In the early 1900s (around 1919), Rhaïs spoke for the Algerian women as an authentic voice for women in Islam. Instead of discussing the challenges that women faced in Algeria under colonial rule, Rhaïs argued that Algerian women were perfectly content in their position. ${ }^{101}$ Instead of discussing the challenges that women faced in Algeria under colonial rule. This representation creates a problematic environment for women who are trying to express their agency and identity.

14. Others were among the about 173,000 Algerians who had served in the French army during World War I or the several hundred thousand more who had assisted the French war effort by working in factories. Many Algerians stayed on in France after 1918, and sent the money they earned there to their relatives in Algeria. In France they became aware of a standard of living higher than any they had known at home and of democratic political concepts, taken for granted by Frenchmen in France, which colons, soldiers, and bureaucrats had refused to apply to the Muslim majority in Algeria. Some Algerians also became acquainted with the pan-Arab nationalism growing in the Middle East.

15. Historical writing on Algeria played a important rule to rise the nationalism. Alexis de Tocqueville, who had never forgotten the effects of the Jacobin terror of 1794 on his own family, had become a parliamentary deputy after the success of his book Democracy in America. In the 1840s he turned his attentions to Algeria and, in his Writings on Empire and Slavery, argued for the robust prosecution of the imperial task. Although aware of the contradictions inherent in his recommendations (he is said to have written, "we have rendered Muslim society much more miserable and much more barbaric than it was before it became acquainted with us"), he persisted in them, because he believed that colonial expansion was the key to preventing democracy from degenerating into popular tyranny. ${ }^{102}$ Daniel Lazare writes: ${ }^{104}$

\section{"Tocqueville claimed to support sovereignty, but at the same time feared that untrammeled popular authority could all too easily devolve into tyranny of the majority. In the absence of any countervailing force, what was to prevent a sovereign people from behaving just as repressively toward their enemies as the ancient régime had behaved toward them?}

Fanon's work also articulates the unity of the oppressed natives in opposition to colonialism with the building of nationalistic sentiment. ${ }^{105}$ Fanon's publication "The Wretched of the Earth" written in 1961 while Fanon was on his death bed in Tunis, provided an emotive and uncompromising view of the relationship between the colonizer and the colonized in Algeria. ${ }^{106}$ This work contributed to the legitimization of the anti-colonial nationalist movement in Algeria during the late1950's onwards. Having banned the book, the French colonizers had certainly identified the book as being influential. ${ }^{107}$

16. Anti-French sentiment had been building for some time the first anti colonial group was formed in 1926, and another, the Algerian People's Party, in 1937 but it was not until 1945 that the independence movement really began to gain momentum. In 1947, de Gaulle refused to relinquish French hold on the colony. The Algerian war for independence broke out in 1954, when the National Liberation Army (ALN), the military arm of the National Liberation Front (FLN) staged guerrilla attacks on French military and communication posts and called on all Muslims to join their struggle.

17. In 1936, the French Prime Minister Blum put forward the Violette Plan that was to grant full citizenship to 25,000 Algerians without renunciation of Muslim status. A new factor influencing Muslim reaction to the reintroduction of that Plan which by that date even many moderates had rejected as inadequate was the shift in Abbas's position from support for integration to the demand for an autonomous state federated with France. Abbas gained the support of the AUMA and formed Friends of the Manifesto and Liberty (Amis du Manifeste et de la Li AML berté) to work for Algerian autonomy with equal rights for both Europeans and Muslims. Within 
a short time, the AML's newspaper, Égalité, claimed 500,000 subscribers, indicating unprecedented interest in independence. By this time, over 350,000 Algerian Muslims (out of a total Algerian Muslim population of nine million) were working in France to support their relatives in Algeria, and many thousands more worked in towns. Messali and his PPA still rejected anything short of independence. However, this was denounced by the European settlers and did not follow through. As a result, Abbas abandoned his assimilations views and in 1943 created the 'Manifesto of the Algerian People' that demanded liberty and equality for Muslims in their own country, in language, education and religion; abolition of colonization together with agrarian reform; full and immediate participation of Muslims in the government of their country and recognition of the political autonomy of Algeria as a sovereign state.

18. In 1908 the Young Algerians (delivered to France's Prime Minister Georges Clemenceau a petition that expressed opposition under the status quo to a proposed policy to conscript Muslim Algerians into the French army. The Armee de Liberation Nationale or ALN was created shortly after the Algerian rising began in 1954. It comprised both internal and external wings (the latter based in Tunisia and Morocco during the war). It was the well armed and trained external wing that made up the bulk of the new Armee Nationale Populaire (ANP) created in 1962. Only some 10,000 of the 50,000-60,000 who had fought in the internal forces were taken into the ANP while the remainder was demobilised. ${ }^{108}$ The regular element of the Algerian armed forces remained at a level of 60,000-70,000 after independence until 1969 when conscription was introduced. Most conscripts however were employed on non-military duties after doing their basic training.

19. In the early 19th and 20th centuries nationalism began to emerge in Asia and Africa. The rise of nationalism in Algeria is the main factor for the independent movement of Algeria. Nationalism is a natural reaction of conquered nations. Nationalism could be defined as a love for a country in forming a nation-state. The emergence of this nationalist spirit is due to the realization that ultimate freedom did not lie with their conquerors, but with themselves: or in other words, freedom ${ }^{109}$ Algerian nationalism developed out of the efforts of three different groups:-

19.1 The first consisted of Algerians who had gained access to French education and earned their living in the French sector. Often called assiilationismts, they pursued gradualist, reformist tactics, shunned illegal actions, and were prepared to consider permanent union with France if the rights of Frenchmen could be extended to native Algerians. This group, originating from the period before World War I, was loosely organized under the Young Algerians and included (in the 1920s) Khaled Ben Hachemi "Emir Khaled", who was the grandson of Abd al Qader, and (in the 1930s) Ferhat Abbas, who later became the first premier of the Provisional Government of the Algerian Republic.

19.2 The second group consisted of Muslim reformers who were inspired by the religious Salafi movement founded in the late 19th century in Egypt by Sheikh Muhammad 'Abduh. Algeria's Islamic reform movement took inspiration from Egyptian reformers Muhammad Abduh and Muhammad Rashid Rida and stressed the Arab and Islamic roots of the country. Starting in the 1920s, the reform ulema, religious scholars, promoted a purification of Islam in Algeria. The reformers favored the adoption of modern methods of inquiry and rejected the superstitions and folk practices of the countryside, actions that brought them into confrontation with the marabouts. The reformers published their own periodicals and books, and established free modern Islamic schools that stressed Arabic language and culture as an alternative to the schools for Muslims operated for many years by the French. Under the dynamic leadership of Shaykh Abd al Hamid Ben Badis, the reformist ulema organized the Association of Algerian Muslim Ulema (Association des Ulema Musulmans Algériens, AUMA) in 1931. Although their support was concentrated in the Constantine area, the AUMA struck a responsive chord among the Muslim masses, with whom it had closer ties than did the other nationalist organizations. As the Islamic reformers gained popularity and influence, the colonial authorities responded in 1933 by refusing them permission to preach in official mosques. This move and similar ones sparked several years of sporadic religious unrest.

19.3. The third group was more proletarian and radical. It was organized among Algerian workers in France in the 1920s under the leadership of Ahmed Messali Hadj and later gained wide support in Algeria. Preaching nationalism without nuance, Messali Hadj was bound to appeal to Algerians, who fully recognized their deprivation. Messali Hadj's strongly nationalistic stance, or even the more muted position of Ben Badis, could have been checked by such gradualist reformers as Ferhat Abbas if only they had been able to show that stepby-step decolonization was possible. Several efforts to liberalize the treatment of native Algerians, promoted by French reformist groups in collaboration with Algerian reformists in the first half of the 20th century, came too late to stem the radical tide.

20. The First World War contributed to the success of the Bolshevik Revolution in Russia in 1917. The impact of this event was global. A host of communist movements spring up in Asia and Africa deriving their inspiration from the success of the Bolsheviks in Russia. The communist rhetoric had its appeal to the colonized masses that were at the receiving end of unbridled exploitative colonial capitalism. In some of the larger countries such as India and Indonesia the communists became important players in the ensuing struggle against colonialism. 
Communism also made inroads into Algeria. A new generation of Muslim leadership emerged in Algeria at the time of World War I and grew to maturity during the 1920s and 1930s. It consisted of a small but influential class of évolués, other Algerians whose perception of themselves and their country had been shaped by wartime experiences, and a body of religious reformers and teachers Others were among the about 173,000 Algerians who had served in the French army during World War I or the several hundred thousand more who had assisted the French war effort by working in factories. Algerian nationalism first appeared after World War I with the emergence of three main nationalist groups. These groups are:

20.1 Star of North Africa (1926): The Star of North Africa was founded by Messali Hadj in 1926 and had a nationalist and radical program that demanded Algerian independence, withdrawal of French troops, and creation of a national army and the nationalization of large estates. It is notable in that it was the first to call for Algerian independence and was affiliated with the French Communist Party and supported by Algerian workers in France. He gave forceful expression to North African aspirations in a declaration read at the Socialiste Internationale Conference in Brussels, Belgium in 1927. It was here that he first put forth a demand for Algerian independence. In addition to independence from France, the Star called for freedom of press and association, a parliament chosen through universal suffrage, confiscation of large estates, and the institution of Arabic schools. The Star was banned in 1929 and operated underground until 1934, when its newspaper reached a circulation of 43,500. Influenced by the Arab nationalist ideas of Lebanese Druze Shakib Arslan, Messali Hadj turned away from communist ideology to a more nationalist outlook, for which the French Communist Party attacked the Star. He returned to Algeria to organize urban workers and peasant farmers and in 1937 founded the Party of the Algerian People "Parti du Peuple Algerien" or PPA to mobilize the Algerian working class at home and in France to improve its situation through political action.

20.2. Federation of Elected Muslims (1930): This organization was founded by Ferhat Abbas in 1930 and had an assimilation agenda that called for representation in the French parliament, suppression of legislation that discriminated adversely against Muslims and equal rights for Muslims without the renunciation of their Muslim status.

20.3 Association of Algerian Muslim Ulema (1931): The Association of Algerian Muslim Ulema was formed by Ben Badis and was originally directed toward religious reform. It firmly opposed assimilation and increased the importance of Islam as a part of the Algerian identity. Ben Badis famously stated that "Islam is my religion, Arabic is my language, Algeria is my country."

21. After World War II, Algerian leaders demanded Muslim equality in exchange for this service. Charles de Gaulle, the leader of the French resistance against Germany during the war and the leader of France's provisional government after the war, agreed to grant French citizenship to certain select Muslims, an unsatisfactory response that resulted in rising tensions between Algerians and their colonizers. The formation of political parties also inspired nationalism. They sensitized colonial people about their human right and especially the need for political independence. The political leaders of the Algerians had been committed to reforming the French Republic by winning equal rights for Algerians within it. In this regard, following political parties played important role to rise of Algerian nationalism:-

21.1. PPA: Hadj Messali founded the Party of the Algerian People (PPA) in 1937 to oppose the new system of French citizenships. He travelled throughout Algeria and in speech after speech roused the people to oppose. It too was suppressed by the French and he was jailed until 1945.

21.2. AML: Abbas gained the support of the AUMA and formed Friends of the Manifesto and Liberty (Amis du Manifeste et de la Liberté, AML) to work for Algerian autonomy with equal rights for both Europeans and Muslims.

21.3. MNA: The Algerian National Movement or Mouvement national algérien or MNA was an organization founded to counteract the efforts of the Front de Liberation Nationale (FLN). It was supported and, some say, partly financed by the French who used it to validate the claim that the FLN was not the sole representative of Algerian desires.

21.4. MTLD: The Movement for the Triumph of Democratic Liberties (MTLD), name proposed by Maiza, was created October 1946 to replace the outlawed Parti du Peuple Algerien (PPA). Messali Hadj remained as its president. The MTLD was created on the same platform as that of the PPA that is full independence for Algeria. 21.5. UDMA: Union Démocratique du Manifeste Algérien: In April 1946, Abbas once again asserted the demands of the manifesto and founded the Democratic Union of the Algerian Manifesto Union Démocratique du Manifeste Algérien, UDMA Abbas called for a free, secular, and republican Algeria loosely federated with France.

21.6. Organisation Spéciale: In 1947, "Organisation Spéciale" (OS) was formed. Their goal was to conduct terrorist operations since political protest through legal channels had been suppressed by the colonial authorities. 21.7. FLN: French actions and growing Algerian nationalism led in 1954 to the creation by Ahmed Ben Bella and his colleagues of the National Liberation Front and a military network throughout Algeria, the National Liberation Army .The Revolutionary Committee of Unity and Action or "Comité Révolutionnaire Front de 
Libération Nationale (CRUA) is a socialist political party in Algeria. Besides it was a group of young Algerian militants, organized in March 1954. The CRUA sought to reconcile the warring factions of the nationalist movement and to wage war against the French colonial presence in Algeria. It was set up on 1 November 1954 as a merger of other smaller groups, to obtain independence for Algeria from France The FLN launched the War of Independence on November 1, 1954, and called on all Algerian Muslims to support it the FLN was undeniably a political group that resorted to armed force and terrorism from the start. The group was immediately qualified as "rebels," "outlaws," and "terrorists." Accordingly, from the first series of FLN attacks, the general government's communiqués evoked acts "committed by small groups of terrorists," whereas the attacks themselves were identified as "menées criminelles" "criminal intrigues or acts". ${ }^{110}$ Later on, the "state of emergency" law again specified that its goal was to fight the "terrorists."

21.8. Movement National Algerian: Ahmed Ben Messali Hadj was an Algerian nationalist politician dedicated to the independence of his homeland from France. He Founded Etoile Nord-africaine, Parti du peuple algerien, Movement National Algerien (Against FLN)-Imprisoned for agitation (after creating Algerian groups) -Was against imperialism, worked with Ho Chi Minh.

21.9. ALN: During the Algerian war for independence, the National Liberation Army "Armée de Libération Nationale" or (ALN) under the command of Col. Houari Boumedienne, acted as the military arm of the FLN. From camps stationed behind Tunisian and Moroccan borders, the ALN's external contingent provided logistical support and weaponry to ALN forces within the country.

22. There were also some political parties which played important rule to emerge the nationalist movement. In 1924 the grandson of the national hero Abdel Kader, emir Khaled, set up the Étoile Nord Africaine among immigrant workers in Paris, with the assistance of the French Communist Party. In 1926 Messali Hadj became its leader. As Messali organised the migrant labourers, Ferhat Abbas organised middle class Algerians in the Fédération des Élus, founded in 1927 around the demand for equal rights with the settlers. ${ }^{111}$ The French Communist Party (PCF) attacked Messali for playing into the settler's hands by supporting their demands for secession. Without PCF support, l'Étoile was easily suppressed by Leon Blum's popular front government in January 1937.

23. As early as the end of the Second World War, the colonial power had experimented with different administrative and legal adjustments; this met with strong opposition from the French Algeria and increased the Algerians' resentment. Of all the countries achieved independence in the immediately post World War II period, Algeria stands out as a tragic exhibit of the brutality of colonial rule. France granted independence to Morocco and Tunisia in March 1956, although their institutions were less developed than those of Algeria, believing that it could continue to exercise control over the other two states through Algeria. Even an exhausted France was unwilling to relinquish its hold on its colonies. After its defeat and expulsion from Indochina (1954), France was even more adamant in holding onto Algeria. Attempts at reforms and proposals for integration of the colony with continental France were quashed leaving no option to the nationalists but to resist.

\section{Political Movements:}

Abd al Qader is recognized and venerated as the first hero of Algerian independence. ${ }^{112}$ From his capital in Tlemcen, his government maintained an army and a bureaucracy, collected taxes, supported education, undertook public works, and established agricultural and manufacturing cooperatives to stimulate economic activity. The French in Algiers viewed with concern the success of a Muslim government and the rapid growth of a viable territorial state that barred the extension of European settlement. Abd al Qader took up the holy war again, destroyed the French settlements on the Mitidja Plain, and at one point advanced to the outskirts of Algiers itself. He struck where the French were weakest and retreated when they advanced against him in greater strength. Gradually, however, superior French resources and manpower and the defection of tribal chieftains took their toll. Reinforcements poured into Algeria after 1840 until Bugeaud had at his disposal 108,000 men, one-third of the French army. Bugeaud's strategy was to destroy Abd al Qader's bases, then to starve the population by destroying its means of subsistence-crops, orchards, and herds. On several occasions, French troops burned or asphyxiated noncombatants hiding from the terror in caves. One by one, the emir's strongholds fell to the French, and many of his ablest commanders were killed or captured so that by 1843 the Muslim state had collapsed. However, Abd al Qader was obliged to surrender to the commander of Oran Province, General Louis de Lamoriciêre, at the end of 1847. Not without cause, his green and white standard was adopted by the Algerian liberation movement during the War of Independence and became the national flag of independent Algeria. ${ }^{113}$ Some of these people were members of the few wealthy Muslim families that had managed to insinuate themselves into the colonial system in the 1890 s and had with difficulty succeeded in obtaining for their sons the French education coveted by progressive Algerians. One of the earliest movements for political reform was an integrationist group, the Young Algerians (Jeunesse Algérienne). Its members were drawn from the small, liberal elite of well educated, middle-class évolués who demanded an opportunity to prove that they were French as well as Muslim. In 1908 they delivered to France's Prime Minister Georges 
Clemenceau a petition that expressed opposition under the status quo to a proposed policy to conscript Muslim Algerians into the French army. If, however, the state granted the Muslims full citizenship, the petition went on opposition to conscription would be dropped. In 1911, in addition to demanding preferential treatment for "the intellectual elements of the country", the group called for an end to unequal taxation, broadening of the franchise, more schools, and protection of indigenous property. The Young Algerians added a significant voice to the reformist movement against French colonial policy that began in 1892 and continued until the outbreak of World War I. In part to reward Muslims who fought and died for France, Clemenceau appointed reform-minded Charles Jonnart as governor general. Reforms promulgated in 1919 and known as the Jonnart Law expanded the number of Muslims permitted to vote to about 425,000. The legislation also removed all voters from the jurisdiction of the humiliating "Code de l'indigénat". The most popular Muslim leader in Algeria after the war was Khalid ibn Hashim, grandson of Abd al Qader and a member of the Young Algerians, although he differed with some members of the group over acceptance of the Jonnart Law. Some Young Algerians were willing to work within the framework set out by the reforms, but Emir Khalid, as he was known, continued to press for the complete Young Algerian program. He was able to win electoral victories in Algiers and to enliven political discourse with his calls for reform and full assimilation, but by 1923 he tired of the struggle and left Algeria, eventually retiring to Damascus. Some of the Young Algerians in 1926 formed the Federation of Elected Natives (Fédération des Élus Indigènes, FEI), as many of the former group's members had joined the circle of Muslims eligible to hold public office. The federation's objectives were the assimilation of the évolués into the French community, with full citizenship but without surrendering their personal status as Muslims, and the eventual integration of Algeria as a full province of France. Other objectives included equal pay for equal work for government employees, abolition of travel restrictions to and from France, abolition of the Code de l'indigénat (which had been reinstituted earlier), and electoral reform. In March 1943, Abbas, who had abandoned assimilation as a viable alternative to self-determination, presented the French administration with the Manifesto of the Algerian People, signed by fifty-six Algerian nationalist and international leaders. Outlining the perceived past and present problems of colonial rule, the manifesto demanded specifically an Algerian constitution that would guarantee immediate and effective political participation and legal equality for Muslims. It called for agrarian reform, recognition of Arabic as an official language on equal terms with French, recognition of a full range of civil liberties, and the freeing of political prisoners of all parties. The demands of Algerian nationalism become unmistakable immediately after the end of the war in Europe. In May 1945 demonstrators carrying Algerian Nationalist flags appear at victory celebrations in the town of Sétif. Scuffles with the police spark an impromptu uprising in which eighty-eight French settlers are killed. Subsequent French reprisals result in at least 1500 Muslim deaths (the official French figure), though other estimates place the death toll as high as 10,000.According to official French figures, 1,500 Muslims died as a result of these countermeasures. Other estimates vary from 6,000 to as high as 45,000 killed. In the aftermath of the Sétif violence, the AML was outlawed, and 5,460 Muslims, including Abbas and many PPA members, were arrested. Abbas deplored the uprising but charged that its repression had taken Algeria "back to the days of the Crusades". In April 1946, UDMA's leader Abbas called for a free, secular, and republican Algeria loosely federated with France. Upon his release from five-year house arrest, Messali Hadj returned to Algeria and formed the Movement for the Triumph of Democratic Liberties (Mouvement pour le Triomphe des Libertés Démocratiques, MTLD), which quickly drew supporters from a broad cross-section of society. Committed to unequivocal independence, the MTLD firmly opposed Abbas's proposal for federation. However some ex-PPA members convinced that independence could only be obtained by military means, continued to operate clandestinely and maintain cells in the Aures Mountains and Kabylie while maintaining membership in the MTLD. In 1947, they formed the OS operating loosely within the MTLD and led by Hocine Ait Ahmed. Their goal was to conduct terrorist operations since political protest through legal channels had been suppressed by the colonial authorities. Ait Ahmed was later succeeded as chief of the OS by Ahmed Ben Bella, one of the early Algerian nationalist leaders. The National Assembly approved the government-proposed Organic Statute of Algeria in August 1947. This law called for the creation of an Algerian Assembly with one house representing Europeans and "meritorious" Muslims, and the other representing the remaining more than 8 million Muslims. The sweeping victory of Messali Hadj's MTLD in the 1947 municipal elections frightened the colons, whose political leaders, through fraud and intimidation, attempted to obtain a result more favorable to them in the following year's first Algerian Assembly voting. The MTLD was allowed nine seats, Abbas's UDMA was given eight, and government-approved "independents" were awarded fifty-five seats. These results may have reassured some of the colons that the nationalists had been rejected by the Muslim community, but the elections suggested to many Muslims that a peaceful solution to Algeria's problems was not possible. At the first session of the colon-controlled Algerian Assembly, an MTLD delegate was arrested at the door, prompting other Muslim representatives to walk out in protest. In 1952 anti-French demonstrations precipitated by the OS led to Messali Hadj's arrest and deportation to France. Internal divisions and attacks by the authorities severely weakened the MTLD, draining its energies. Mr. Ben Bella led Algeria to independence from France before becoming 
president in 1963. But he became disillusioned with French rule on his return to Algeria after the war, and was elected municipal councilor for the anti-colonialist "Movement for the Triumph of Democratic Liberties." Ben Bella created a new underground action committee to replace the OS, which had been broken up by the French police in 1950. When the movement was declared illegal, Mr. Ben Bella went underground. In May 1951, he was arrested. He fled to Cairo where he planned the 1954 uprising which began Algeria's war of independence. ${ }^{114}$ The new group, the Revolutionary Committee of Unity and Action (Comité Révolutionnaire d'Unite et d'Action, CRUA), was based in Cairo. Known as the chefs historiques (historical chiefs), the group's nine original leaders-Hocine Ait Ahmed, Mohamed Boudiaf, Belkacem Krim, Rabah Bitat, Larbi Ben M'Hidi, Mourad Didouch, Moustafa Ben Boulaid, Mohamed Khider, and Ben Bella-were considered the leaders of the Algerian War of Independence. Between March and October 1954, the CRUA organized a military network in Algeria comprising six military regions. The leaders of these regions and their followers became known as the "internals". Ben Bella, Khider, and Ait Ahmed formed the External Delegation in Cairo. Encouraged by Egypt's President Gamal Abdul Nasser their role was to gain foreign support for the rebellion and to acquire arms, supplies, and funds for the wilaya commanders. In October the CRUA renamed itself the National Liberation Front (FLN), which assumed responsibility for the political direction of the revolution. The National Liberation Army (ALN), the FLN's military arm, was to conduct the War of Independence within Algeria. During the night of 31 October 1954 several coordinated terrorist attacks are carried out on French police and military establishments. A manifesto issued on November 1 declares them to be the work of the recently formed FLN, stating also that the political aim of the FLN is a fully independent Algeria. Every resident in the country is promised citizenship of the proposed new republic, with full rights, if willing to adopt Algerian nationality. On 1 November 1954, the FLN guerillas launched attacks on military and police establishments. After eight years of war, a ceasefire was reached and a new independent government of the Republic of Algeria was set up under Ahmed Ben Bella.1 November has since been celebrated as the National Day of Algeria. In September 1955 Ferhat Abbas's political standing in Algeria and reputation as a moderate nationalist, acceptable to the West, helped him become president of the provisional Algerian nationalist government-in-exile, the GPRA, from 1958 until 1961. He lost his place to Benyoucef Ben Khedda, which may have been a reason for his decision to join Ahmed Ben Bella's and Houari Boumédiène's Tlemcen Group in opposition to the GPRA, which was subsequently dismantled. Due to Pakistan's support to the cause of Algerian struggle for independence and selfdetermination, Ferhat Abbas was given a Pakistani diplomatic passport for his foreign travels. However, The Algerian War had begun on November 1, 1954 when the first major attack of the FLN was launched, consisting of "scores of scores of spectacular attacks." ${ }^{115}$ The battle took place on August 20, 1955 and centered on the Algerian town of Philippeville, though the FLN also made attacks on surrounding areas. There were 134 fellagha killed in the streets of Philippeville, and several hundred more wounded; the French citizens killed were 71 and the FLN also killed 52 Muslims, many of whom were prominent politicians. ${ }^{116}$ From camps stationed behind Tunisian and Moroccan borders, the ALN's external contingent provided logistical support and weaponry to ALN forces within the country. The war for independence continued until March 18, 1962, when the French at last signed a cease-fire agreement with the FLN at Évian-les-Bains and made provisions for future economic and social cooperation. At the height of the war, French army numbers in Algeria finally reached some 400,000, sufficient at last to quell the resistance, but not to stop the tide of history at the conference table: finally, in a referendum in 1962, the country voted overwhelmingly for independence. The Algerian war for independence ended in 1962 when French President Charles De Gaulle pronounced Algeria an independent country on July 3.

\section{References:}

[1]. Neil. McMaster, Burning the Veil: The Algerian war and the 'emancipation' of Muslim women (Manchester: Manchester University Press, 2009), 1

[2]. Miriam Cooke, Deconstructing War Discourse: Women's Participation in the Algerian Revolution (Women and International Development, Michigan State University, June 1989), 4

[3]. Official website of the Muslim500, www, Themuslim500com, Retrieved 19 January 2012.

[4]. MacMaster, Op.cit., 1

[5]. A. Robert, "Colonial Nationalism and Decolonization," Greater France: A History of French Overseas Expansion (New York: St. Martin's Press, 1996), 15

[6]. M. Alexander, M. Evans, J. Keiger, The Algerian War and the French Army, 1954-62: Experiences, Images, Testimonies (Palgrave Macmillan, 2002), 6

[7]. John Atherton, Democracies at war against terrorism, in Samy Cohen (ed.), Democracies at war against terrorism, The French State Faced with the Algerian Nationalists (1954-1962): A War against Terrorism? (Palgrave Macmillan, 2008), 280

[8]. Algeria -Country Study (Library of the US Congress, December 1993), 395-400

[9]. ISLAMIST THREAT, PIERRE VERMEREN, THE NORTH AFRICAN EDUCATIONAL CHALLENGE: FROM COLONISATION TO THE CURRENT ALLEDGED, Mediterranean Journal of Educational Studies, 2009, 14(2), 50

[10]. Algeria: A Country Study, ibid, 24

[11]. D. Prochaska, Making Algeria French, ibid, 62

[12]. A Special International Report Prepared by The Washington Times Advertising Department, http://www.washtimes.com, July 2, 1999 
[13]. Richard Wall, Algeria 1830: Legacy of an Occupation (LewRockwell.com, April 22, 2004), 6

[14]. Prof. Dr. Nazeer Ahmed, The War of Algeria's Independence-1954-62, Powered by WordPress.com, 14

[15]. J. P. Entelis, Algeria: The Revolution institutionalized (Boulder, West view Press.1986), 30

[16]. O. W. Abi Mershed, Apostles of Modernity: St. Simonians and the Civilizing Mission in Algeria (Stanford: Stanford University Press, 2010), 25

[17]. Patricia M.E. Lorcin, "Rome and France in Africa: Recovering Colonial Algeria's Latin Past," French Historical Studies, 25(2), 2002, 295-329

[18]. Julia Clancy-Smith, "Marginality and Migration: Europe's Social Outcasts in Pre-colonial Tunisia, 1830-81," in Eugene Rogan (ed.) Outside In: On the Margins of the Modern Middle East (London: I.B. Tauris, 2002), 90

[19]. Gérard Crespo and Jean-Jacques Jordi, L'Immigration Espagnole dans l'Algérois de 1830-1914 (Versailles: Éditions de l' Atlanthrope, 1991), 21

[20]. Michel Levallois, IsmaÿlUrbain: une autre conquète de l’Algérie (Paris: Maisonneuve et Larose, 2001), 15

[21]. John P Entelis, Op.cit., 30

[22]. David Prochaska, Making Algeria French: Colonialism in Bône, 1870-1920 (Cambridge: Cambridge University Press, 1990), 62

[23]. J.D. Latham, From Muslim Spain to Barbary: Studies in the History and Culture of the Muslim West (London, 1986), 55

[24]. D. Prochaska, Making Algeria French, Op.cit., 149

[25]. Gérard Crespo and Jean-Jacques Jordi, L'Immigration Espagnole dans l'Algérois de 1830-1914 (Versailles: Éditions de 1' Atlanthrope, 1991), 8

[26]. Clancy-Smith, Julia, "The Maghrib and the Mediterranean World in the Nineteenth Century: Illicit Exchanges, Migrants, and Social Marginals." in Michael le Gall and Kenneth Perkins (ed.) The Maghrib in Question (Austin, T.X.: The University of Texas Press, 1997), 220

[27]. Crespo, Gérard and Jean-Jacques Jordi, Op.cit.

[28]. CAOM, Huertas, "Les Populations Espagnols en Oranie," Box ALG GGA 8 X 302

[29]. O. W. Abi Mershed, Op.cit., 25

[30]. D. Prochaska, Making Algeria French: Colonialism in Bône, 1870-1920 (Cambridge: Cambridge University Press, 1990), 67

[31]. J. R. Lehning, To Be A Citizen: The Political Culture of the Early French Third Republic (Ithaca: Cornell University Press, 2001), 130; Gary Wilder, The French Imperial Nation-State, (Chicago: The University of Chicago Press, 2005), 2

[32]. Raymond F. Betts, The False Dawn: European Imperialism in the Nineteenth Century (St. Paul: University of Minnesota Press, 1975), 14.

[33]. Alice Conklin, A Mission to Civilize: The Republican Idea of Empire in France and West Africa, 1895-1930 (Stanford: Stanford University Press, 1997), 2-3; Osama W. Abi Mershed, Apostles of Modernity: St. Simonians and the Civilizing Mission in Algeria (Stanford: Stanford University Press, 2010), 25

[34]. Léon Galibert, L'Algérie — Ancienne et Moderne (1st ed.), Paris, 1844, 249

[35]. D. Prochaska, Op.cit., 151.

[36]. [C.R. Ageron, Modern Algeria: A History from 1830 to the Present, eds. And trans. Michael Brett (Trenton: Africa World Press, 1990), 53

[37]. France History Archive Algeria and the defeat of French Humanism .Source: Chapter six of The 'Death of the Subject' Explained, by James Heartfield (Sheffield Hallam University, 2002)

[38]. Library of the US Congress, Algeria -Country Study, ibid, 23

[39]. Kateb, Européens, "Indigènes" et Juifs en Algérie (1830-1962), 33

[40]. A Special International Report Prepared by The Washington Times Advertising Department, http://www.washtimes.com, July 2 1999; Paul Deschamps et al. Les colonies et la vie française pendant huit siècles, (Paris: Firmin-Didot et Cie, 1934 ), 194-5

[41]. Lehning, To be a Citizen, 136

[42]. J.Ruedy, Modern Algeria: The Origins and Development of a Nation (Indianapolis: Indiana University Press, 1992), 110

[43]. Algeria - History \& Background, Education Encyclopedia - StateUniversity.com/ http://education.stateuniversity.com, 3

[44]. Christine Souriau “ Arabisation and French Culture in the Maghreb" in Decolonisation and After: The British and French Experience, ed. W. H. Morris-Jones and Georges Fisher kin Studies in Commonwealth Politics and History No.7 ( London :Frank Cass and Company,1980), 321

[45]. Naiad N. Wong, Frayed memories and incomplete indentities : The impact of the Algerian War on The pieds noirs, Algerian Women, and the Algerian State (University of Hawal'1 Library, May,2005), 2

[46]. Francis Gouda, “ Good Mothers, Medeas or Jezebels : Feminine Imargery in colonial and Anti colonial Rhetoric in the Dutch East Indies ; in Domesticating the Empire : Race, Gender, and Family life in French and Dutch Colonialism, ed. and trans, Julia ClancySmith and Frances Gouda ( Charlottesville: University of Virginia Press, 1999), 198

[47]. Ruedy. John, Op.cit., 115

[48]. Ibid

[49]. Ibid

[50]. R. Aaron, Op.cit., 81

[51]. Ibid, 167

[52]. Neil. MacMaster, Colonial Migrants and Racism: Algerians in France, 1900-62 (New York: St Martin’s Press, 1997), 3

[53]. Naiad N. Wong, Op.cit., 5

[54]. Stone. Martin, The Agony of Algeria, (New York, Colombia University Press, 1997), P.23

[55]. J-F Lyotard, Political Writings, 1959, 248

[56]. Robert Aaron, Op.cit., 169

[57]. Amrane-Minne, Daniele Djamila, and Farida Abu-Haidar. "Women and Politics in Algeria from the War of Independence to Our Day." Research in African Literatures 30.3 (1999), 62

[58]. Mallory Anne Warner, The veil as exception and difference in French discourse and policy, College of Liberal Arts \& Social Sciences Theses and Dissertations, (2011), Paper 75, 31

[59]. MacMaster, Op.cit., 29-30

[60]. Heggoy. A. Andrew. "On the Evolution of Algerian Women" African Studies Review, 17(2), 1974, 449-456

[61]. Cherifa Bouatta, Evolution of the Women's Movement in Contemporary Algeria : Organization, Objectives and Prospects, (Ed.) Valentine M. Moghadam, (UNU/WIDER research project on Global Economic Restructuring and Women Workers in Industrializing and Transition Economies, University of Algiers, February 1997), 1

[62]. Lazreg, Marnia. Torture and the Twilight of Empire: From Algiers to Baghdad (Princeton: Princeton University Press, 2008 ), 163 
[63]. Vince, Natalya. "To be a moudjahida in Independent Algeria: Itineraries and Memories of Women Veterans of the Algerian War," PhD diss.(University of London, 2008), 42

[64]. Sarah Kleinman, Advisor: Dr. Sheryl Kroen, Resistance, Representation, and War: Algerian Women, the French Army, and the Djamila Boupacha Case (Spring 2012), 18

[65]. C.Miriam. Deconstructing War Discourse: Women's Participation in the Algerian Revolution (Michigan State University, 1989) 2

[66]. Neil. Macmaster, "The Colonial "Emancipation" of Algerian Women: the Marriage Law of 1959 and the Failure of Legislation on Women's Rights in the Post-Independence Era." Vienna Journal of African Studies 12 (2007), 91-92

[67]. Ibid, 96

[68]. Ibid, 96

[69]. Ibid, 96

[70]. Ibid, 91-92

[71]. C. Miriam, Op.cit., 7

[72]. Joseph, Suad, Women and Power in the Middle East, Susan Slyomovics (ed.), (University of Pennsylvania Press, 2000), 28

[73]. Nikki R. Keddie, Women in the Middle East: Past and Present, (Princeton University Press, 2006), 142

[74]. Neil. Macmaster, "The Colonial "Emancipation" of Algerian Women: the Marriage Law of 1959 and the Failure of Legislation on Women's Rights in the Post-Independence Era." Vienna Journal of African Studies 12 (2007), 92

[75]. Macmaster, Op.cit., 92-93

[76]. Vince. Natalya, "Transgressing Boundaries: Gender, Race, Religion, and "Françaises Musulmanes" during the Algerian War of Independence." French Historical Studies 33.3 (2010), 446

[77]. Ibid, 454

[78]. Ibid, 455

[79]. H.L. Marie-Aimee, "Women, Nationalism, and Religion in the Algerian Liberation Struggle" Badran, Margot, and Miriam Cooke, (eds.) Opening the Gates: An Anthology of Arab, 10; Macmaster, Neil, Op.cit., 97

[80]. Turshen. Meredith "Algerian Women in the Liberation Struggle and the Civil War: From Active Participants to Passive Victims?" Social Research 69.3 (2002), 891

[81]. Vince, Natalya, Op.cit., 459

[82]. A. Leonhardt, Op.cit., 12

[83]. James D. Le Sueur "Decolonizing 'French Universalism': Reconsidering the Impact of the Algerian War on French Intellectuals," The Journal of North African Studies 6(1), 2001, 167

[84]. R. Seferdjeli, "Fight with us, women, and we will emancipate you': France, the FLN and the Struggle over Women during the Algerian War of National Liberation 1954-1962," PhD diss. (London School of Economics, 2004), 87

[85]. Raphaëlle Branche, "Sexual Violence in the Algerian War," in Brutality and Desire: War and Sexuality in Europe's Twentieth Century, Dagmar Herzog (ed.) (New York: Palgrave MacMillan, 2011), 249.

[86]. Seferdjeli, Op.cit., 94

[87]. Vince. Natalya, Op.cit., 452

[88]. Lazreg, Op.cit., 3

[89]. Lazreg, ibid, 3

[90]. Lazreg, ibid, 26.

[91]. James D. LeSueur, "Torture and the Decolonization of French Algeria: nationalism, 'race' and violence during colonial incarceration," in Colonial and Post-Colonial Incarceration, ed. Graeme Harper (New York, Continuum, 2001), 165

[92]. Ibid

[93]. MacMaster, Burning the Veil, Op.cit., 223

[94]. Lazreg, Torture, Op.cit., 163

[95]. Dr. Sheryl Kroen, Resistance, Representation, and War: Algerian Women, the French Army, and the Djamila Boupacha Case Sarah Kleinman, Honors Projects, (2012). Paper 6, 1-35

[96]. Vince, "To be a mujahida," Op.cit., 42

[97]. Lazreg, Torture, Op.cit., 130

[98]. Lazreg, ibid, 154

[99]. Price, Roger, A Concise History of France. 2nd Ed. (Cambridge: Cambridge University Press, 2005) 341

[100]. A. Andrew. Heggoy, Op.cit., 449-456

[101]. J. A. Boittin, "Feminist Mediations of the Exotic: French Algeria, Morocco, and Tunisia, 1921-39" Gender and History, 22(1) $131-150$

[102]. Ibid

[103]. Alexis de Tocqueville, Writings on Empire and Slavery, Jennifer Pitts (ed.), (Johns Hopkins University Press, September 2003), 12

[104]. Daniel Lazare, L'Amerique, Mon Amour, The Nation, issue dated April 26, 2004

[105]. F.Fanon, The Wretched of the Earth, Farrington C. (Trans), (Grove Press, New York, 1961), 35-38

[106]. Ibid.

[107]. M .S Annedith, Building the Nation: Narrating Women and the Algerian War, (Sabanci University, Turkey), 3

[108]. John Keegan, page 13 "World Armies", ISBN 0-333-17236-1

[109]. N. S.Yurni Ahmad, Ki-Soo Eun, The Rise of Nationalism among South Korean Youth and Democracy: An Analysis (World Academy of Science, Engineering and Technology 64, 2012), 308

[110]. Jean-Charles Jauffret et Maurice Vaïsse (eds.), Militaires et guérilla dans la guerre d'Algérie, (Brussels: Complexe, 2001), 447-467

[111]. Ian Clegg, Workers' Self Management in Algeria (New York: Monthly Review Press, 1971) 32

[112]. Ibid .26

[113]. BBC NEWS Africa, 11 April 2012

[114]. P. Aussaresse, The Battle of the Casbah. (Enigma Books, 2006), 1

[115]. Adam Shatz, "The Torture of Algiers," (NY Review of Books 21 November 2002), 49(18), 23 